Sains Malaysiana 49(1)(2020): 11-18

http://dx.doi.org/10.17576/jsm-2020-4901-02

\title{
Genetic Variability for Ginning Outturn and Association among Fiber Quality Traits in an Upland Cotton Global Germplasm Collection
}

(Variasi Genetik untuk Hasil Kasar Gin dan Perkaitan antara Sifat Kualiti Gentian pada Pengumpulan Germplasma Sejagat Kapas Tanah Tinggi)

\author{
Khezir Hayat \& Adem BARdaK*
}

\begin{abstract}
Gossypium genus is the main source of natural fiber all over the world. Limitations in conventional breeding program for genetic improvement are due to the complexity and limited knowledge about economically important traits. A diverse germplasm was screened at East Mediterranean Transitional Zone Agricultural Research Institute of Kahramanmaras and at farmer field in Diyarbakir Turkey during 2016 to assess variation for ginning outturn and fiber quality. The gene pool was consisted of global collections namely Acala Maxa, Fibermax810 and Stoneville-453 derived from USA, Delcerro (Venezuela), Carmen (Australia), Taskent-6, Samarkand Uzbek (Uzbekistan), Allepo-40 (Syria), Albania-6172 (Albania), Lachata, Nata (Spain), NSCH777 (India) and elite cultivars from Turkey including Carla, Nazilli84S, Ozbek142 and Fantom. Analysis of variance showed highly significant differences among genotypes for all traits on pooled data basis. Correlation analysis showed significant relationship among fiber traits such as fiber length, fiber strength and micronaire. It was concluded that some genotypes can be used as potential parents in breeding such as AB-80 and BA440 for increasing lint percentage, YB-230 and Flora for fiber length, and Delcerro and Menderes for fiber strength.
\end{abstract}

Keywords: Correlation; cotton; fiber quality; germplasm; variation

\section{ABSTRAK}

Genus Gossypium adalah sumber utama serat semula jadi di seluruh dunia. Keterbatasan dalam program pembiakan konvensional untuk penambahbaikan genetik adalah disebabkan oleh kerumitan dan pengetahuan terhad tentang ciri penting daripada segi ekonomi. Pelbagai germplasma telah disaring di Institut Kajian Pertanian Zon Peralihan Mediterranean Timur di Kahramanmaras dan di ladang petani di Diyarbakir Turki pada tahun 2016 untuk menilai variasi untuk hasil kasar gin dan kualiti gentian. Koleksi gen ini terdiri daripada koleksi global seperti Acala Maxa, Fibermax810 dan Stoneville-453 yang berasal dari Amerika Syarikat, Delcerro (Venezuela), Carmen (Australia), Taskent-6, Samarkand Uzbek (Uzbekistan), Allepo-40 (Syria) 6172 (Albania), Lachata, Nata (Sepanyol), NSCH777 (India) dan kultivar elit dari Turki termasuk Carla, Nazilli84S, Ozbek142 dan Fantom. Analisis varians menunjukkan perbezaan yang sangat signifikan antara genotip untuk semua sifat berdasarkan data yang dikumpulkan. Analisis korelasi menunjukkan hubungan yang signifikan antara ciri gentian seperti panjang gentian, kekuatan gentian dan mikronaire. Adalah disimpulkan bahawa sesetengah genotip boleh digunakan sebagai potensi induk dalam pembiakbakaan seperti AB-80 dan BA440 untuk meningkatkan peratusan benang, YB-230 dan Flora untuk panjang gentian serta Delcerro dan Menderes untuk kekuatan gentian.

Kata kunci: Germplasma; kapas; korelasi; kualiti gentian; variasi

\section{INTRODUCTION}

Cotton is a crop of immense importance being a dominant source of fiber and oil from cotton seed all over the world (Bardak \& Bolek 2012). The improvement of cotton fiber quality has become more important because of changes in spinning technology and ever-increasing demands of fibre. Cotton is grown in more than 80 countries and contributes to the world economy as a raw material for textile industry (Tan et al. 2015). In 2017, cotton was grown on an area of 29.27 million ha with production of 105.34 million bales in the world where India, China, United States of America,
Pakistan and Brazil were the top growers (FAO 2017). In Turkey, cotton covers 416,000 ha area and is grown in three main regions namely Agean, Mediterranean (Antalya province and Cukurova) and Southeastern Anatolia with the overall lint production of 756,000 tons (Anonymous 2017). A total of $2.5 \%$ of global fiber yield is shared by Turkey which is ranked in the seventh position.

Efforts for broadening the genetic base of Gossypium genus have not generated successful outcomes due to the complex and large genetic architecture of its genome. The improvement of fiber yield and quality is a difficult task as 
these are influenced by agronomic and climatic conditions. Lint yield manifested stable increase till 1980's (Bridge et al. 1971; Culp \& Green 1992). The intensity of improvement for lint production has deteriorated since the 1980's (Meredith et al. 1997). Fiber quality was accomplished as joint contribution of all fiber quality traits in a precise way (Meritt 2014). Owing to limited genetic diversity in elite cotton cultivars (Iqbal et al. 2001), the efforts to enhance fiber production and upgrade quality has been confined (Smith \& Coyle 1997).

Ginning outturn (GOT) is a vital component for fiber yield as it is directly associated with lint and it should be analysed with care for fiber quality improvement. It has been reported that yield can be boosted 3\% with $1 \%$ rise in ginning outturn (Saleem et al. 2010). Fiber length, fiber strength, fiber fineness, fiber elongation and other traits constitute fiber quality (Ali et al. 2008; Poehlman \& Sleper 1995). Phenotypical screening of economic traits is highly influenced by climatic factors and many genes which all contribute to decrease in production (Karademir et al. 2011). Sezener et al. (2006) showed that high GOT \% is good for devising strategy for fiber quality improvement. It has been well documented that tight negative relationship was found among essential fiber traits and lint production (Meredith \& Bridge 1971). Yield and fiber traits were inversely correlated with each other as shown from the analysis among two continents under different years (Clement et al. 2012). Zeng et al. (2009) witnessed that GOT was directly related to fiber strength and fineness with significance. Nonetheless, inverse relationship is prevalent among yield and fiber quality, the highly effective strategy is to be observed through refinement of the traits. In this research, upland cotton germplasm was screened for assessing variability in ginning outturn and other fiber quality traits.

\section{Materials AND Methods}

In 2016, the Gossypium germplasm consisting of 289 genotypes was used for assessing variation related to fiber traits. The trials were grown on 24th April 2016 at the East Mediterranean Transitional Zone Agricultural Research Institute of Kahramanmaras and Diyarbakir (Bismil) at grower field in Turkey using augmented blocks experimental design $6 \mathrm{~m}$ plot length and $0.2 \mathrm{~m}$ intrarow and $0.7 \mathrm{~m}$ interrow spaces. Recommended agronomical practices were done while pest control measures were applied accordingly.

As a whole, 50 opened bolls were harvested manually from 10 consecutive plants leaving the border plants from each entry at both locations. Ginning outturn (GOT \%) was calculated according to Singh (2004) with the formula shown herewith:

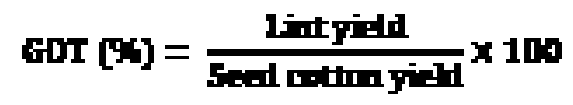

The first experimental trail was conducted at the East Mediterranean Transitional Zone Agricultural Research
Institute in Kahramanmaras which is located at $37^{\circ} 53^{\prime} \mathrm{N}$, $36^{\circ} 58^{\prime} \mathrm{E}$. The climate type of Kahramanmaras city is a typical Mediterranean climate. During cropping season, maximum temperature varied from 30.8 to $42.8^{\circ} \mathrm{C}$ in contrast with 21.2 to $36^{\circ} \mathrm{C}$ long-term data while mean temperature ranged from 15.5 to $28.5^{\circ} \mathrm{C}$ (Table 1). The second trial was conducted at Diyarbakır which is located in southeastern part of Turkey at $37^{\circ} 49^{\prime} 55.5^{\prime} \mathrm{N}$, $40^{\circ} 32^{\prime} 01.8^{\prime \prime} \mathrm{E}$. Here, the maximum temperature varied from 28.0 to $40.3^{\circ} \mathrm{C}$ during cropping season whereas longterm temperatures were between 35.3 and $45.9^{\circ} \mathrm{C}$, and the mean temperature ranged from 13.8 to $31.1^{\circ} \mathrm{C}$ (Table 1). When the long term measurements for Diyarbakir are considered, it becomes clear that the climate in this city is harsh as it is very hot in summer and too cold in winter. Additionally, $496 \mathrm{~mm}$ of rainfall was recorded annually for the region (Anonymous 2016).

The fiber quality analyses of all fiber samples were performed using a HVI M-1000 (Usterhouse Switzerland) in a controlled condition $\left(20^{\circ} \mathrm{C}\right.$ and $\left.65 \% \mathrm{RH}\right)$ at the Testing Center of Cotton Fiber Quality in the Nazar Textile Company in Kahramanmaras. The fiber traits determined using HVI were fiber length ( $\mathrm{mm}$ ) as upper half mean length (UHML), uniformity index, fiber strength $\left(\mathrm{g} \mathrm{tex}^{-1}\right)$, micronaire value $\left(\mu \mathrm{g}\right.$ inch $\left.^{-1}\right)$, maturity and elongation expressed as percentage.

Analysis of variance (ANOVA), variability parameters and Pearson coefficient of correlation analysis of fiber quality were determined. Frequency curves were constructed using Microsoft Office.

\section{RESUlTS AND Discussion}

Means, standard error and variation in the form of standard deviation for different traits on combined basis are mentioned in Table 1. All the characters exhibited wide variation among germplasm as ranged from 4.1 to $46.1 \%$, 21.9 to $35.6 \mathrm{~mm}, 78.4$ to $87.2 \%, 2.97$ to $5.9 \mu \mathrm{g} \mathrm{inch}^{-1}, 21.67$ to $44.6 \mathrm{~g} \mathrm{tex}^{-1}, 83.0$ to $91.0 \%$ and 3.7 to $7.7 \%$ for ginning outturn, fiber length, uniformity index, micronaire, strength, maturity and fiber elongation, respectively. While variation on standard deviation fluctuated from 0.01 to 4.2 among all entries (Table 2). The highest coefficient of variability was found for fiber uniformity $(13.9 \%)$ and for fiber elongation $(9.7 \%)$ while lowest in maturity. As an ultimate goal was to find genotypes with good economical traits, the means were pooled and variation was observed. Analysis of variance showed highly significant differences among all fiber quality traits (Table 3 ). The genotypes were found highly significant for fiber traits. It was found that locations were highly significant for all traits.

The association among gene pool entries showed that there is a considerable variability in the collection. The ginning outturn changed between 4.65 and $47.93 \%$ and the average was $37.23 \%$ in Kahramanmaras location. A total of 29 genotypes had high ginning outturn compared to GW-TEX, 26 to STV 468 (Stoneville 468) and 35 had more GOT (\%) in-contrast to BA119. The ginning outturn 
TABLE 1. Cliamatic data during experiment at Kahramanmaras and Diyarbakır locations

\begin{tabular}{|c|c|c|c|c|c|c|c|c|c|}
\hline & \multirow{2}{*}{ 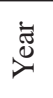 } & \multirow[t]{2}{*}{ Climatic parameters } & \multicolumn{7}{|c|}{ Months } \\
\hline & & & April & May & June & July & August & Sept. & Oct. \\
\hline \multirow{12}{*}{ 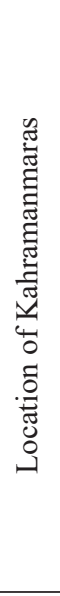 } & \multirow{6}{*}{ 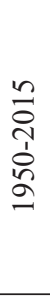 } & Max. Temp. (oC) & 21.2 & 26.7 & 31.9 & 36 & 36 & 32.4 & 26 \\
\hline & & Min. Temp. (oC) & 9.9 & 14.1 & 18.8 & 22 & 22.2 & 18.4 & 13 \\
\hline & & Av. Temp. (oC) & 15.5 & 20.3 & 25.2 & 28 & 28.5 & 25.2 & 19 \\
\hline & & Rainfall (mm) & 72.7 & 40 & 6.8 & 1 & 0.9 & 8.9 & 45 \\
\hline & & Humidity (\%) & 57.7 & 54.4 & 49 & 51 & 51.9 & 49.2 & 54 \\
\hline & & Wind intensity $\left(\mathrm{ms}^{-1}\right)$ & 2.1 & 2.4 & 3.4 & 3.9 & 3.4 & 2.5 & 1.3 \\
\hline & \multirow{6}{*}{$\stackrel{0}{\stackrel{0}{\sim}}$} & Max. Temp. (oC) & 30.8 & 35.5 & 41.3 & 42 & 42.8 & 38.7 & 33 \\
\hline & & Min. Temp. (oC) & 8.6 & 9.7 & 14 & 20 & 21.4 & 11.3 & 9.2 \\
\hline & & Av. Temp. (oC) & 18.8 & 21.8 & 26.8 & 30 & 30.7 & 24.9 & 19 \\
\hline & & Rainfall (mm) & 17.6 & 18.7 & 17.9 & 1 & 1 & 23.7 & 11 \\
\hline & & Humidity (\%) & 41.2 & 47.9 & 40.3 & 37 & 40.9 & 39.2 & 39 \\
\hline & & Wind intensity $\left(\mathrm{ms}^{-1}\right)$ & 1.3 & 1.7 & 1.9 & 2.1 & 1.9 & 1.7 & 1.1 \\
\hline \multirow{12}{*}{ 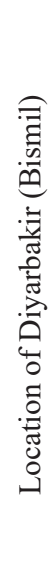 } & \multirow{6}{*}{ 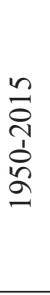 } & Max. Temp. (oC) & 35.3 & 38.1 & 42 & 45 & 45.9 & 42 & 36 \\
\hline & & Min. Temp. (oC) & -6.1 & 0.8 & 6 & 11 & 13.8 & 5.2 & -1.2 \\
\hline & & Av. Temp. (oC) & 13.8 & 19.2 & 26.2 & 31 & 30.4 & 24.9 & 17 \\
\hline & & Rainfall (mm) & 11.7 & 9.3 & 2.9 & 0.5 & 0.3 & 1.2 & 5.8 \\
\hline & & Humidity (\%) & 13.8 & 19.2 & 26.3 & 31 & 30.4 & 38.7 & 41 \\
\hline & & Wind intensity $\left(\mathrm{ms}^{-1}\right)$ & 68.4 & 44.4 & 8.8 & 0.5 & 0.4 & 4.2 & 33 \\
\hline & \multirow{6}{*}{$\stackrel{\circ}{\stackrel{\sim}{\sim}}$} & Max. Temp. (oC) & 28 & 33 & 34.4 & 39 & 40.3 & 31.7 & 27 \\
\hline & & Min. Temp. (oC) & 6.8 & 11.2 & 17.2 & 22 & 21.9 & 23.6 & 11 \\
\hline & & Av. Temp. (oC) & 15.1 & 19.2 & 25.8 & 31 & 31 & 15.2 & 19 \\
\hline & & Rainfall (mm) & 0.5 & 1.1 & 14.5 & 0 & 0.3 & 0 & 0.8 \\
\hline & & Humidity (\%) & 55.1 & 51.1 & 31.2 & 22 & 21.8 & 28.9 & 36 \\
\hline & & Wind intensity $\left(\mathrm{ms}^{-1}\right)$ & 9.3 & 10.9 & 12.4 & 15 & 9.6 & 12.4 & 7.2 \\
\hline
\end{tabular}

TABLE 2. Descripitive statistics for fiber traits

\begin{tabular}{lccccccc}
\hline & GOT & FL & UI & FF & MAT & STR & FE \\
\hline Mean + SE & $37.35+0.24$ & $28.83+0.11$ & $83.57+0.08$ & $4.55+0.03$ & $0.87+0.00$ & $31.05+0.17$ & $5.56+0.04$ \\
S. D & 4.22 & 1.92 & 1.52 & 0.45 & 0.012 & 2.91 & 0.64 \\
Minimum & 4.1 & 21.9 & 78.4 & 2.97 & 0.83 & 21.67 & 3.7 \\
Maximum & 46.1 & 35.6 & 87.2 & 5.9 & 0.90 & 44.6 & 7.7 \\
CV (\%) & 2.9 & 3.0 & 13.9 & 5.4 & 1.1 & 9.2 & 9.7 \\
\hline
\end{tabular}

SE: Standard error GOT: Ginning outturn; FL: Fiber length (mm); UIN: Uniformity Index (\%); FF: Fiber fineness $\left(\mu \mathrm{g}\right.$ inch $\left.^{-1}\right)$; STR: Fiber strength $\left(\mathrm{g} \mathrm{tex}^{-1}\right)$; MAT: Maturity (ratio); FE: Fiber elongation (\%)

changed between 26.79 and $46.15 \%$ and the average was $37.97 \%$ in Diyarbakır (Bismil) location. While in second location, 21 genotypes had high GOT (\%) compared to standard GW-TEX, 23 to Stoneville 468 and 33 had more ginning outturn in contrast with standard BA119. Mean value of $37.4 \%$ was found for ginning outturn among the entries where AB80 had highest value of $46.1 \%$ followed by BA440, Ozbek142 and Carla with 44.5, 44.4 and 43.3\%, respectively, while minimum at $4.1 \%$ for PI528426 compared to the standards STV 468, GW-TEX and BA119 which were found to have 41.3, 41.2 and $40.9 \%$, respectively. Since it is the need to fulfill demands from growers and textile industry, breeding measures should be taken for boosting yield and lint percentage. It has been shown from the results (Figure 1) that 20 (6.2\%) genotypes had better ginning outturn than best standard STV 468 (41.3\%). Ginning outturn is a trait which has a major role in production; likewise the same pattern was observed in germplasm by Khan et al. (2010). It was observed that considerable variation was found among the genotypes for ginning outturn and other fiber traits. These findings were similar to earlier studies (Sezener et al. 2006) that showed 
TABLE 3. Means squares for fiber traits

\begin{tabular}{|c|c|c|c|c|c|c|c|c|}
\hline SOV & $\mathrm{DF}$ & GOT & FL & UI & $\mathrm{FF}$ & MAT & STR & FE \\
\hline $\mathrm{L}$ & 1 & $79.79 * *$ & $33.12 * *$ & $26.36^{* * *}$ & $26.12 * *$ & $0.071^{*}$ & $384.47 * *$ & $236.63 * *$ \\
\hline B & 7 & 0.72 & 1.26 & 3.91 & 0.13 & 0.0001 & 5.77 & 0.41 \\
\hline G & 288 & $18.03 * *$ & $6.83 * *$ & $3.51 *$ & $0.36^{* *}$ & $0.0002 * *$ & $16.42 * *$ & $0.94 * *$ \\
\hline $\mathrm{G}^{*} \mathrm{~L}$ & 288 & $4.88 * *$ & 1.16 & $1.99 * *$ & 0.15 & $0.0001 * *$ & 6.19 & 0.31 \\
\hline $\mathrm{E}$ & 35 & 1.14 & 0.77 & 1.35 & 0.06 & 0.0001 & 8.22 & 0.28 \\
\hline $\mathrm{T}$ & 619 & 7550.8 & 2390 & 1688.3 & 182.35 & 0.22 & 7337.42 & 634.92 \\
\hline
\end{tabular}

SOV: Source of variation; L: Location; B: Block; G: Genotype; G*L: Genotype*Location; E: Error; T:Total; GOT (\%): Ginning outturn; FL: Fiber length (mm); UIN: Uniformity Index (\%); FF: Fiber fineness ( $\left.\mu \mathrm{g} \mathrm{inch}^{-1}\right)$; STR: Fiber strength $\left(\mathrm{g}\right.$ tex $\left.{ }^{-1}\right)$; MAT: Maturity (ratio); FE: Fiber elongation (\%)

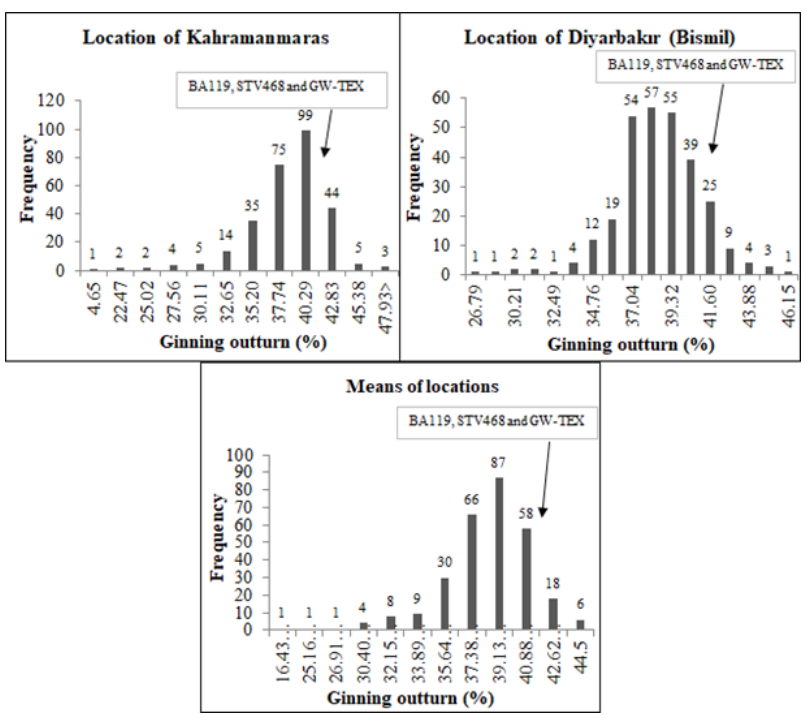

FIGURE 1. Frequency distribution for ginning outturn differences for genotype $\mathrm{x}$ environment interaction for fiber properties. Since many reports have been published but it is still compulsory to use sources with good lint yield and one such source was found in AB80.

The fiber length changed between 21.5 and $35.28 \mathrm{~mm}$ in Kahramanmaras. Twelve genotypes had more fiber length compared to GW-TEX while 10 genotypes were found to be higher in length in contrast with STV468 and BA119. While it varied from 21.3 to $33.7 \mathrm{~mm}, 22$ genotypes were found to have high staple length than standards BA119 and STV468 in Diyarbakir. Moreover, nine genotypes had better fiber length than GW-TEX (Figure 2). Fiber length ranged from 21.9 to $36.6 \mathrm{~mm}$ among germplasm entries as maximum of $36.6 \mathrm{~mm}$ was found in YB230, while minimum of $21.9 \mathrm{~mm}$ was found in PI528420 compared to $29.9 \mathrm{~mm}$ in GW-TEX. SPEARS3 (67), Flora and PI528875 were found to be extra-long staple with $35.5,33.7$ and $33.1 \mathrm{~mm}$, respectively, on pooled data. Of the entries, $25.6 \%$ were found to be long compared to the best standard GW-TEX $(29.9 \mathrm{~mm})$. It was reported that fiber length changes according to genotypes and environment (Wang et al. 2013). Behery (1993) showed

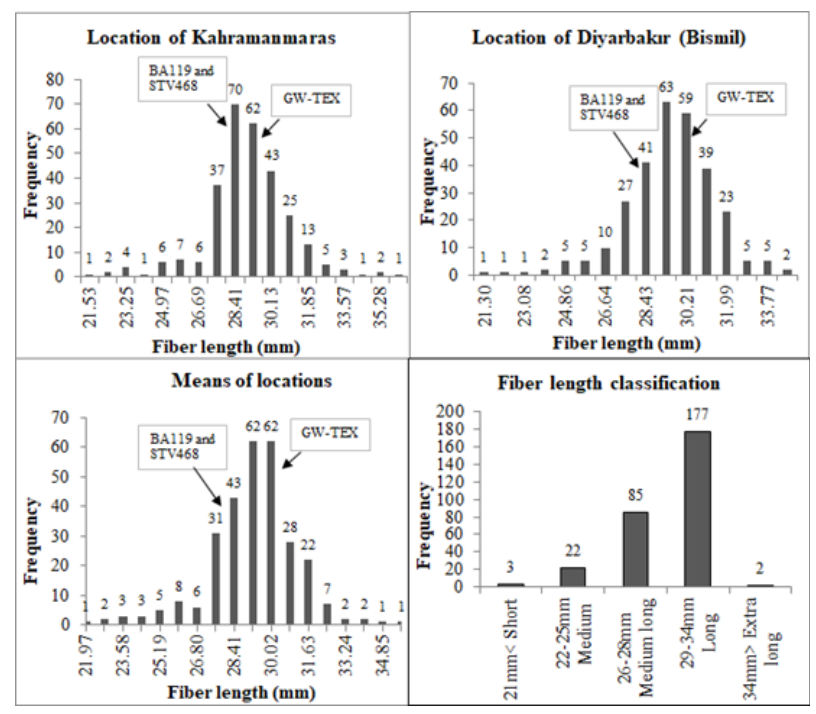

FIGURE 2. Frequency distribution for fiber length(mm) and classification

that it is impossible to have actual value for length of fiber as fibers vary a lot even in an individual seed as stretched fibers are found on chalazal part while small are on micropylar end. The variability found in current studies was in accordance with Elci et al. (2014). Fiber length is classified into five different classes as all specified types of garments are compulsory (Bradow \& Davidson 2000). Majority of the genotypes were included in long staple class (Figure 2).

Uniformity index ranged from 76.9 to 86.9 at Kahramanmaras while it was found 75.4 to 78.8 At the second location, it was observed that four genotypes had high uniformity index compared to standards namely BA119, STV468 and GW-TEX. Means for uniformity index ranged from 78.4 to $87.2 \%$ as highest was found in Sealand1 while lowest was in PI528450 compared to standards on combined basis. Majority of the entries, 144 (49.8\%), were in high class and 49 genotypes $(17.1 \%)$ were found very high compared to superior standard, STV468 $(84.89 \%)$ (Figure 3$)$. The class of garments is inferior with small uniformity ratio as it exhibits the more frequency of small fibers which ultimately affects yarn. Majority of the 


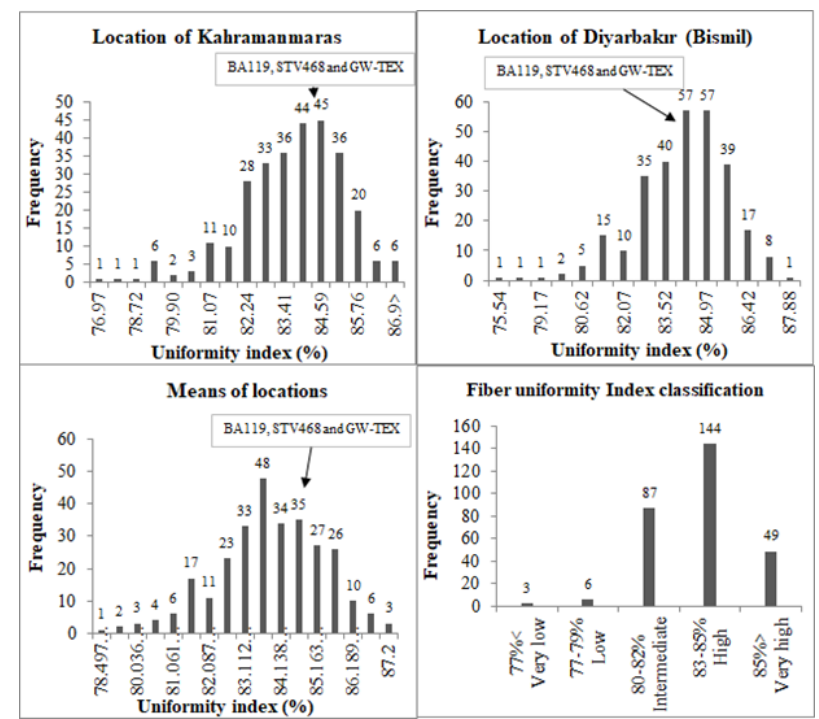

FIGURE 3. Frequency distribution for fiber uniformity index (\%) and classification

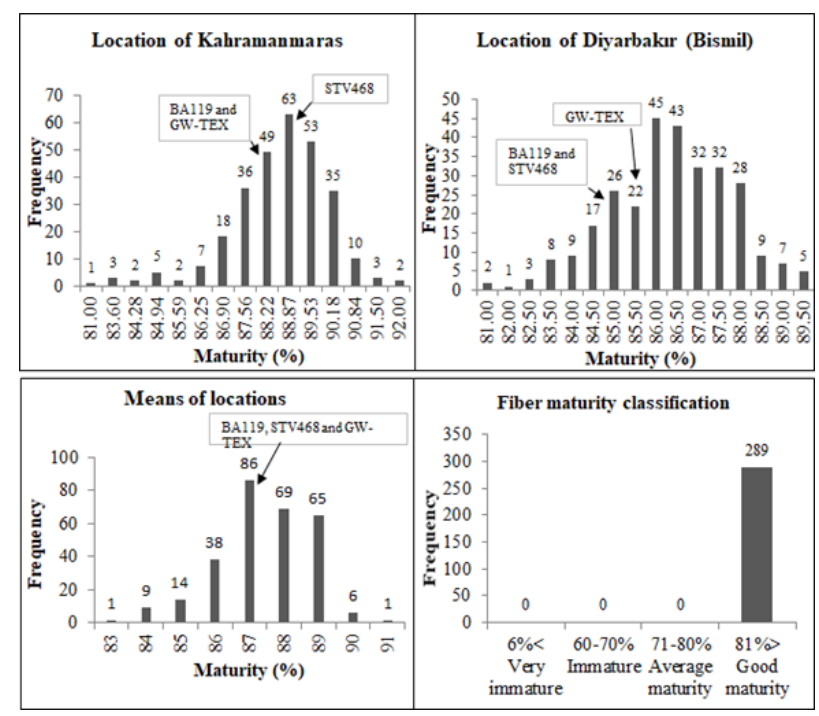

FIGURE 5. Frequency distribution for fiber maturity and classification

entries were found in high class which was in agreement with Akiscan et al. (2012).

Micronaire varied from 2.9 to $6.5\left(\mu \mathrm{g} \mathrm{inch}{ }^{-1}\right)$ in Kahramanmaras. A total of 106 genotypes were found to be finer than BA119 and GW-TEX while 88 had more fineness than STV468 (Figure 4). Moreover, it changed from 3.1 to $5.6\left(\mu \mathrm{g} \mathrm{inch}^{-1}\right)$ at the second location where majority of the genotypes had good fineness than standards. Micronaire values ranged from 2.9 to $5.9 \mu \mathrm{g} \mathrm{inch}^{-1}$ as was the highest in YB157 and Cun S-2 had minimum of 3.2 compared to STV468 with maximum of $4.7 \mu \mathrm{g} \mathrm{inch}^{-1}$ on combined basis. The genotypes were differentiated into different groups from fine to coarse (Bradow \& Davidnois 2000). Coarse cultivars include TX 0091-2, Kashinat, Ozbek with 142, 5.5, 5.7 and $5.9 \mu \mathrm{g} \mathrm{inch}^{-1}$, respectively.

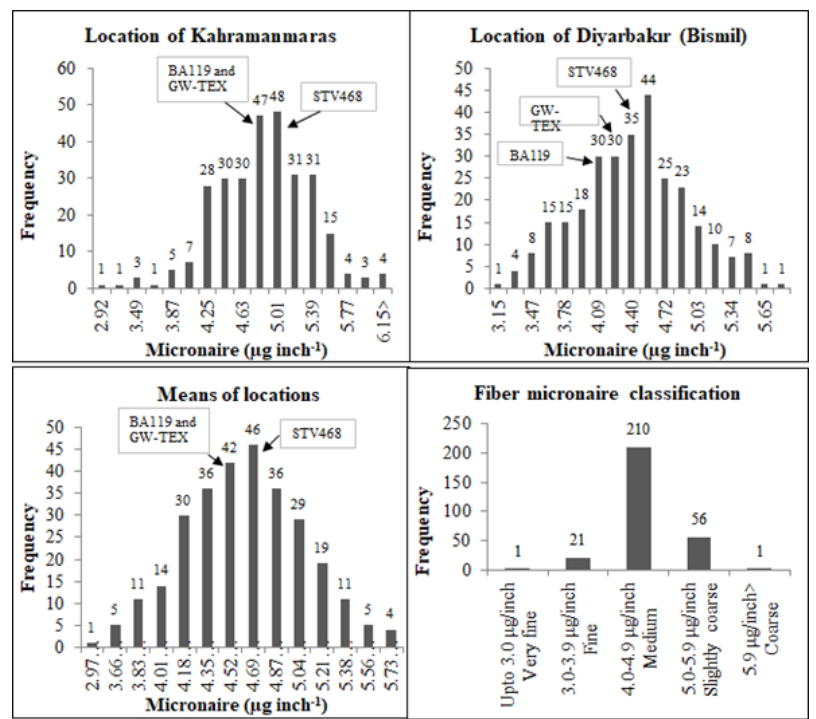

FIGURE 4. Frequency distribution for fiber micronaire $(\mu \mathrm{g}$ inch $^{-1}$ ) and classification

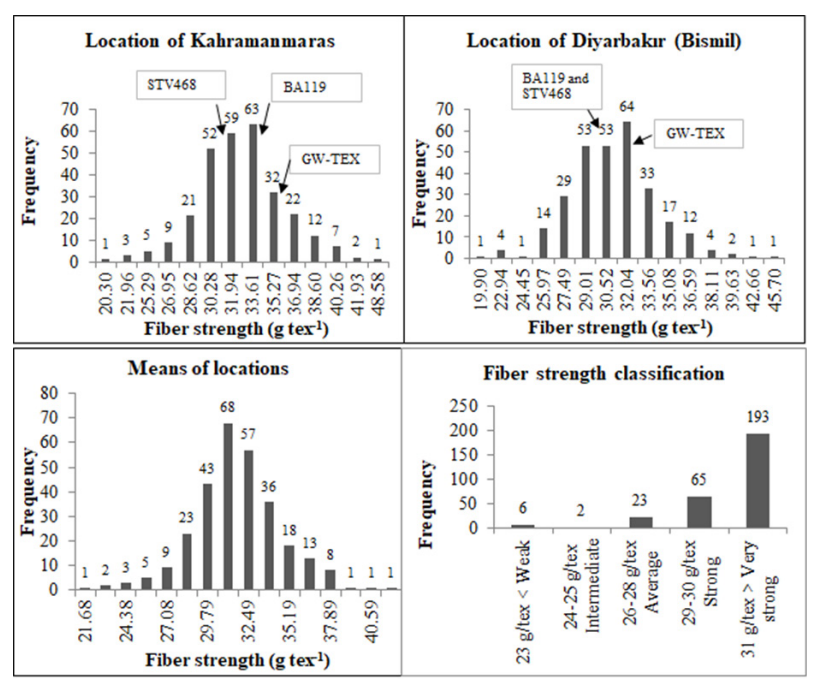

FIGURE 6. Frequency distribution for fiber strength (g tex-1) and classification

Of the genotypes, $42.7 \%$ were found better compared to the best check GW-TEX with micronaire of $4.4 \mu \mathrm{g} \mathrm{inch}^{-1}$ (Figure 4). Zulkadir and Bolek (2014) found the same results in their germplasm.

A total of 81 to $92 \%$ maturity in terms of percentage were observed in Kahramanmaras where 14 genotypes had better fiber maturity compared to BA-119 and GW-TEX. While it varied from 81.0 to $89.5 \%, 74$ genotypes were found to have highly mature compared to GW-TEX and 70 had more mature fiber than BA119 and STV468 in Diyarbakir. Mean values for maturity ratio ranged from 83 to $91 \%$ compared to the best standard, GW-TEX, with $87 \%$ on combined basis. Maximum ratio was observed in YB157 (91\%) followed by TX $0175-1(90 \%)$ and minimum in Togo. Most of the genotypes were found to be mature as 
frequency curves were also constructed using means (Figure 5). During dyeing, high tearing of fiber, deformity and low absorption of dye are produced due to high immature fibers (Paudel et al. 2013). Therefore, it is compulsory that fiber should be mature to fulfill the needs of all stakeholders related to cotton. While in the present investigations variation was higher and according to breeding objectives high maturity results in better consistency up to the length of fiber. Karademir et al. (2010) and Koli et al. (2014) also observed the same variation among germplasm lines.

Fiber strength varied from 20.3 to $48.5\left(\mathrm{~g} \mathrm{tex}^{-1}\right)$ where 80 genotypes were found to be stronger than GW-TEX, four better than STV468 and two were higher than BA119 in Kahramanmaras. Moreover, it changed from 19.9 to 45.7 $\left(\mathrm{g} \mathrm{tex}^{-1}\right)$ at the second location where 11 genotypes had more fiber strength than STV468 and BA119. On combined basis, mean values ranged from 21.6 to $44.6 \mathrm{~g} \mathrm{tex}^{-1}$ for fiber strength. Delcerro had highest strength of 44.6 followed by Menderes 2005 with $39.5 \mathrm{~g}^{-1} \mathrm{x}^{-1}$ while Sari Gelin had the lowest fiber strength $\left(21.7 \mathrm{~g} \mathrm{tex}^{-1}\right)$. A total of $67.0 \%$ genotypes were found in a very strong category while $21.8 \%$ genotypes of total collection had more strength $\mathrm{g} \mathrm{tex}^{-1}$ compared to superior check GW-TEX with $33.1 \mathrm{~g} \mathrm{tex}^{-1}$ (Figure 6). Strength is of vital importance from industry perspectives as it is directly involved with yarn firmness. If the fiber is having greater strength, then it can resist the power during spinning and will result in quality yarn. Same pattern for fiber strength among genotypes was showed earlier (Elci et al. 2014; Zeng et al. 2011).

Fiber elongation varied from 2.9 to 7.31 where 34 genotypes were found to be more flexible than GW-TEX, and 52 were found better than STV468 and BA119 in Kahramanmaras. Moreover, it changed from 4.1 to 9.3 at the second location where 16 genotypes were more flexible than GW-TEX and BA119. The genotypes varied from 3.7 to $7.7 \%$ on mean basis compared to $6.4 \%$ in STV468 while $\mathrm{NSCH}-777$ had maximum fiber elongation (7.8\%). It is the property of substance that whenever force is applied then its texture is changed but cotton has a unique feature. Five different groups were assigned to fiber elongation designated as very low to very high ranged from less than $5 \%$ to more than $7.6 \%$ (Figure 7 ). It has been shown that elongation contributes a lot to yarn manufacturing and different values for this trait has been determined. The genotypes with more elongation have more valuable fabrics as there is no deformity; therefore, the present variation will be a good source for fiber quality improvement (Koli et al. 2014).

Fiber quality traits associations were determined on pooled data via Pearson correlation coefficient (Table 4). Ginning outturn showed positive and significant associations with fiber length and uniformity index. Fiber length had highly significant positive correlation with strength $\left(0.457^{* *}\right)$ and uniformity index $\left(0.253^{* *}\right)$ but negative between micronaire $(-0.194 * *)$. Uniformity index was highly significantly associated with fiber length $(0.253 * *)$ and strength $(0.220 * *)$. Fiber fineness showed highly significant negative relation $(-0.140 * *)$ with elongation.

The crop scientists should be aware about the impact of ginning outturn on yield when strategy is made for boosting yield using this parameter for selection. It has been reported that improvement of GOT \% has direct association with uniformity and fiber length (Zeng et al. 2009). Liu et al. (2011) witnessed that GOT is directly related to fiber strength and fineness with significance and the same relationship was found in current study but not significant. This kind of behavior might be due to inclusion of genes with more than one effect (Smith \& Coyle 1997). As it was reported earlier by Zeng et al. (2009) that maturity ratio is directly related with strength and indirectly to elongation, we also found the same relationship. It was shown from association analysis that strength and elongation are indirectly associated with each other. The effect of gene remains among the permanent populations and will not be disturbed which result in stable association. Earlier opposite association has been reported among ginning outturn and fiber length and micronaire while direct association between ginning outturn and strength and micronaire (Percy et al. 2006).

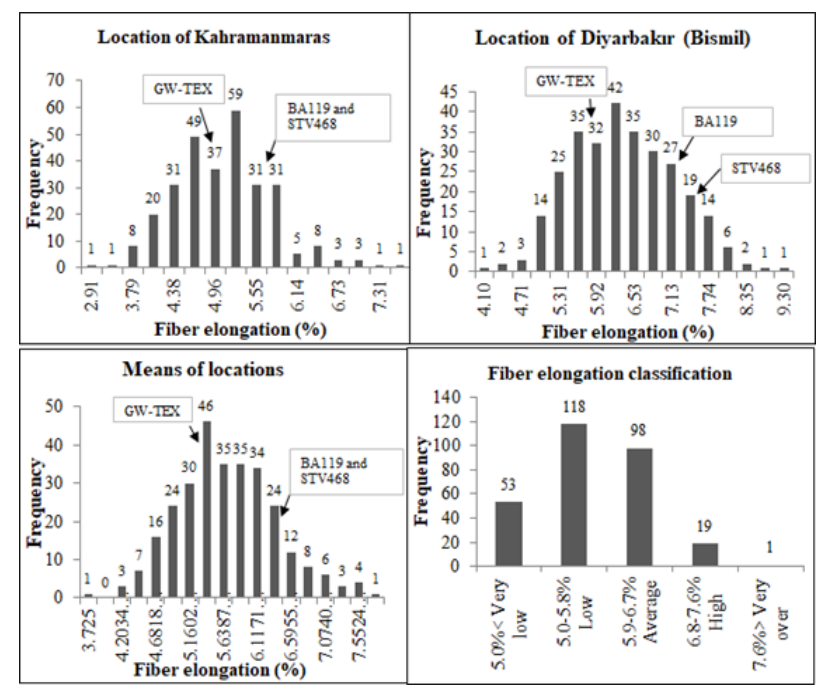

FIGURE 7. Frequency distribution for fiber elongation and classification

\section{CONCLUSION}

The results of the present study showed that considerable variation was observed among fiber traits in Kahramanmras germplasm collection. It was shown that some genotypes can be used as potential parents in variety development such as AB80, BA440 and Carla for increasing lint percentage, Sealand1, Flora, SPEARS3(67) and PI528875 for fiber length, Delcerro for fiber strength, and NSCH-777 for increasing fiber elongation. Meanwhile, Acala Maxa, Nazilli342, Acala Prema, NP Ozbek100, Flash, Julia, Claudia and Candia had multiple desired fiber traits. As a result, cotton breeders have a big task to refine fiber quality without compromising yield. 
TABLE 4. Correlation for fiber quality traits

\begin{tabular}{|c|c|c|c|c|c|c|c|}
\hline & GOT & $\mathrm{FL}$ & UI & $\mathrm{FF}$ & MAT & SR & $\mathrm{FE}$ \\
\hline GOT & 1 & & & & & & \\
\hline $\mathrm{FL}$ & $0.091^{*}$ & 1 & & & & & \\
\hline UI & $0.120 * *$ & $0.253^{* *}$ & 1 & & & & \\
\hline $\mathrm{FF}$ & 0.008 & $-0.194 * *$ & 0.005 & 1 & & & \\
\hline MAT & -0.013 & -0.061 & -0.045 & $0.502 * *$ & 1 & & \\
\hline SR & 0.064 & $0.457 * *$ & $0.220 * *$ & -0.063 & $0.099^{*}$ & 1 & \\
\hline $\mathrm{FE}$ & 0.048 & $-0.1104 *$ & *0.103 & $-0.140 * *$ & $-0.466 * *$ & $-0.212 * *$ & 1 \\
\hline
\end{tabular}

GOT (\%): Ginning outturn; FL: Fiber length (mm); UIN: Uniformity Index (\%); FF: Fiber fineness ( $\left.\mu \mathrm{g} \mathrm{inch}^{-1}\right)$; STR: Fiber strength $\left(\mathrm{g} \mathrm{tex}^{-1}\right)$; MAT: Maturity (ratio); FE: Fiber elongation (\%)

\section{ACKNOWLEDGEMENTS}

The authors gratefully acknowledge Kahramanmaras Sutcu Imam University for Graduate Student funding Project No. 2017/4-24D for conducting fiber analysis. This study is a part of Phenotypic screening of germplasm of the Dr. Khezir Hayat's PhD thesis work and Dr. Adem Bardak was a supervisior.

\section{REFERENCES}

Akiscan, Y. 2012. Determination of genetic improvement on fiber quality traits in some cotton cultivars released between 1980 and 2009 in Turkey. Süleyman Demirel Üniversitesi Ziraat Fakültesi Dergisi 7(2): 32-40.

Ali, M. A., Khan, I. A., Awan, S. I., Shiraz, A. \& Shahid, N. 2008. Genetics of fibre quality traits in cotton (Gossypium hirsutum L.). Australian Journal of Crop Science 2(1): 1017.

Anonymous, 2017. Turkish Statistical Institute, Plant Production Statistical. http://www.tuik.gov.tr.

Anonymous. 2016. Temperature and rainfall values for Kahramanmaras and Diyarbakir province. Turkish State Meteorological Service, Climatic Data, Kahramanmaras.

Bardak, A. \& Bolek, Y. 2012. Genetic diversity of diploid and tetraploid cottons determined by SSR and ISSR markers. Turkish Journal of Field Crops 17(2): 139-144.

Bradow, J. W. \& Davidonis, H. D. 2000. Quantification of fiber quality and the cotton production-processing interface: A physiologist perspective. Journal of Cotton Science 4: 3464.

Behery, H. M. 1993. Short-Fiber Content and Uniformity Index in Cotton. International Cotton Advisory Committee review article on cotton production research No. 4, Wallingford: CAB Int. p. 40.

Bridge, R. R., Meredith, W. R. \& Chism, J. F. 1971. Comparative performance of obsolete varieties and current varieties of upland cotton. Crop Science 11(1): 29-32.

Clement, J. D., Constable, G. A., Stiller, W. N. \& Liu, S. M. 2012. Negative associations still exist between yield and fibre quality in cotton breeding programs in Australia and USA. Field Crops Research 128: 1-7.

Culp, T. W. \& Green, C. C. 1992. Performance of obsolete and current cultivars and Pee Dee germplasm lines of cotton. Crop Science 32(1): 35-41.
Elci, E., Akiscan, Y. \& Akgol, L. 2014. Genetic diversity of Turkish commercial cotton varieties revealed by molecular markers and fiber quality traits. Turkish Journal of Botany 38(6): 1274-1286.

FAO. 2017. FAOSTAT: FAO Statistical Databases. Rome: Food and Agriculture Organization.

Liu, S., Llewellyn, D. J., Stiller, W. N., Jacobs, J., Lacape, J. M. \& Constable, G. A. 2011. Heritability and predicted selection response of yield components and fibre properties in an interspecific derived line of cotton. Euphytica 178(3): 309-320.

Iqbal, M. J., Aziz, N., Saeed, N. A., Zafar, Y. \& Malik, K. A. 2001. Genetic diversity evaluation of some elite cotton cultivars by RAPD analysis. Theoretical and Applied Genetics 94(1): 139-144.

Karademir, C., Karademir, E., Ekinci, R. \& Berekatoglu, K. 2011. Yield and fiber quality properties of cotton (Gossypium hirsutum L.) under water stress and non-stress conditions. African Journal of Biotechnology 10(59): 12575-12583.

Karademir, E., Karademir, C., Ekinci, R. \& Gencer, O. 2010. Relationship between yield, fiber length and other fiberrelated traits in advanced cotton strains. Notulae Botanicae Horti Agrobotanici Cluj-Napoca 38(3): 111-116.

Koli, G. P., Patil, D. V. \& Bagade, A.B. 2014. Comparative study for fiber quality parameters in cotton (Gossypium sp. L.). International Journal of Current Microbiology and Applied Sciences 3(11): 628-632.

Khan, N. U., Marwat, K. B., Farhatullah, G. H., Batool, S., Makhdoom, K. \& Ahmad, W. 2010. Genetic variation and heritability for cotton seed, fiber and oil traits in Gossypium hirsutum L. Pakistan Journal of Botany 42(1): 615-625.

Meredith, W. R. Jr. \& Bridge, R. R. 1971. Breakup of linkage blocks in cotton, Gossypium hirsutum L. Crop Science 11(5): 695-698.

Meredith, W. R. Jr., Heitholt, J. J., Pettigrew, W. T. \& Rayburn, S. T. 1997. Comparsion of obsolete and modern cultivars at two nitrogen levels. Crop Science 37(5): 1453-1457.

Meritt, B. T. 2014. Transgressive segregation for fiber properties of three populations in cotton. MSc. Thesis. Texas A\&M. (Unpublished).

Paudel, D. R., Hequet, D. F. \& Abidi, N. 2013. Evaluation of cotton fiber maturity measurements. Industrial Crops and Products 45: 435-444.

Percy, R. G., Cantrell, R. G. \& Zhang, J. 2006. Genetic variation for agronomic and fiber properties in an introgressed 
recombinant inbred population of cotton. Crop Science 46(3): 1311-1317.

Poehlman, J. M. \& Sleper, D. A. 1995. Breeding Cotton. Breeding Field Crops. 4th ed. Iowa State: University Press/ Ames. pp. 369-387.

Saleem, M. F., Bilal, M. F., Awais, M., Shahid, M.Q. \& Anjum, S.A. 2010. Effect of nitrogen on seed cotton yield and fiber qualities of cotton (Gossypium hirsutum L.) cultivars. The Journal of Animal \& Plant Sciences 20(1): 23-27.

Sezener, V., Kabakci, Y. I. \& Aydin, U. 2006. A clustering study on selection of parents in cotton breeding. Asian Journal of Plant Sciences 5(6): 1031-1034.

Singh, P. 2004. Cotton Breeding. New Delhi: Kalyani Publishers Ludhiana. p: 295.

Smith, C. W. \& Coyle, G. G. 1997. Association of fiber quality parameters and within-boll yield components in upland cotton. Crop Science 37(6): 1775-1779.

Tan, Z. Y., Fang, X. M., Tang, S. Y., Zhang, J., Liu, D., Teng, Z. H., Li, L., Ni, H. J., Zheng, F. M., Liu, D., Zhang, T. F., Paterson, A. H. \& Zhang, Z. S. 2015. Genetic map and QTL controlling fiber quality traits in upland cotton (Gossypium hirsutum L.). Euphytica. 203(3): 615-628.

Wang, X., Yu, Y. S., Wu, J., Zhang, Q. \& Lin, X. 2013. Intraspecific linkage map construction and QTL mapping of yield and fiber quality of Gossypium barbadense. Australian Journal of Crop Science 7(9): 1252-1261.

Zeng, L., Meredith, W. R. Jr., Gutiérrez, O. A. \& Boykin, D. L. 2009. Identification of associations between SSR markers and fiber traits in an exotic germplasm derived from multiple crosses among Gossypium tetraploid species. Theoretical and Applied Genetics 119(1): 93-103.

Zeng, L., Meredith, W. R. Jr. \& Boykin, D. L. 2011. Germplasm potential for continuing improvement of fiber quality in upland cotton: Combining ability for lint yield and fiber quality. Crop Science 51(1): 60-68.

Zulkadir, G. \& Bolek, Y. 2014. Polymorphism of the genes related to cotton fiber elongation. Nevsehir Journal of Science and Technology 3(1): 79-98.

Khezir Hayat

Central Cotton Research Institute

Multan

Pakistan

\section{Adem Bardak*}

Department of Agricultural Biotechnology

Faculty of Agriculture

Kahramanmaras Sutcu Imam University

46100 Kahramanmaras

Turkey

*Corresponding author; email: adembardak@ksu.edu.tr

Received: 25 March 2019

Accepted: 18 October 2019 